\title{
LEGAL CONDITIONS FOR THE PROTECTION OF THREE DIMENSIONAL SIGNS IN TRADEMARK LAW
}

\begin{abstract}
The need to define three-dimensional trademarks and determine the conditions for their registration has arisen as a consequence of increasingly rapid technological development. The changes in the market and the changes in behaviour of economic entities have resulted in the use of signs for marking goods that differ significantly from the traditional trademarks. The concept of protection of a three-dimensional shape is relatively new and it is necessary to clearly define the conditions for its protection as a trademark. What causes a problem is the fact that the mark, in this case, represents the product itself, which implies that such signs of this sort lack distinctiveness, and it is not clear what is protected by that mark. The analysis of the afore-mentioned cases from practice, presented by the author, aims to show the differences in opinions of the courts regarding the criteria by which it will be assessed whether the condition of distinctiveness is satisfied in a specific case or not. The main reason for the lack of reliable criteria is the hasty regulation of unconventional signs and the lack of the harmonized, clear rules both at the level of the European Union and at the global level. The author considers it necessary for the World Trade Organization or the World Intellectual Property Organization to offer guidelines within which an adequate protection of unconventional signs will be provided at the national level in order to eliminate the state of legal uncertainty that may arise when applying for protection of threedimensional signs.
\end{abstract}

\footnotetext{
* LLM, a doctoral candidate at the Faculty of Law, The University of Kragujevac; A teaching assistant at the Faculty of Law for Commerce and Judiciary in Novi Sad, The University of Business Academy in Novi Sad, Republic of Serbia, e-mail: milica.petrovic@pravni-fakultet.info
} 
Keywords: three-dimensional sign, unconventional sign, trademark law, intellectual property law.

\section{Introduction}

Historically, the appearance of signs on products occurs with the exchange of goods. Therefore, in a way, the historical roots of trademark rights can be sensed in the practice of marking goods intended for sale on the market. Thus, in ancient Athens, artisans marked their goods, to draw the attention of customers to the origin of the product, but also to guarantee the quality of their products. Also, the fact is that already in ancient Rome, blacksmiths marked their signs by imprinting them on the blades of swords that they made (Mwirigi \& Krishnan, 2019, p. 914). Even in the Middle Ages, when the volume of trade decreased, there were examples of the use of signs to label the products. For example, precisely because of the widespread use of signs for labelling goods and services, the first act was passed in England in 1266 to protect the signs (it was an act that allowed bakers to put their signs on the bread they produce) (Lukose, 2015, p. 198).

The development of industry, marketing, and trade under capitalism led to the need to advance the protection of signs through trademarks. The modern consumer in a modern, capitalist society, daily encounters a large number of products, which have almost identical characteristics and products from different, numerous, manufacturers. By placing an appropriate sign on its goods or type of service, the economic entity gives the consumer the opportunity to be informed about the characteristics of the product itself or the type of service that will be provided, which will make it easier for him to make a decision and be able to identify the manufacturer or service organization.

Initially, signs protected by law were mostly verbal (composed of words, letters, numbers, and combinations thereof) or graphic (composed of images and colors) (Marković \& Popović, 2018, p. 151). Industrial capitalism in the 21 st century, with global overproduction of goods and increasing competition in the market, economic entities are forced to be different and to stand out among the mass producers of similar goods or organizations that provide similar services and thus try to attract as many consumers. Precisely because of this, out of the need to achieve the most direct communication and better connection with customers, today we encounter signs that we describe as unconventional signs (or non-traditional), such as three-dimensional signs, sound signs, fragrance-aroma signs, texture-touch signs, holographic signs, 
motion signs, and even entire slogans (Setiawan, Sulistianingsih \& Bhakti Yudistira, 2017, p.125).

Nevertheless, argues Lukose (2015), most states through national legislation provide some degree of protection for unconventional signs; there are isolated examples of legislation, such as the Indian one, whose intellectual property laws do not contain any rules on such signs, nor the procedure for their registration.

\section{The concept of three-dimensional signs}

A three-dimensional sign is a type of unconventional trademark that is characterized by the fact that it extends into all three dimensions, therefore, it has length, width, and height. Due to the described characteristics, during the registration, the applicant for the registration of such a sign is obliged to submit a three-dimensional representation of that sign by presenting it from several different angles. In addition to the three-dimensional symbol, such a sign may contain other elements such as words, colours, or two-dimensional symbols. (Chu-Hui \& Liang-Hsiu, 2017, p. 623). A three-dimensional sign is a sign that consists of the shape of the product, i.e., the packaging of the product.

The concept of protection of a three-dimensional sign is relatively new, which raises the question of whether the described sign can be protected by a trademark or not. This issue, for example, became particularly relevant in the United Kingdom after 1994, when the Trademarks Act was adopted and was resolved by providing the possibility of granting protection through trademarks to the three-dimensional signs, under the same conditions as other traditional signs, under the condition that the form for which protection is sought must not be that which arises from the nature of the goods themselves (Karki, 2005, p. 504).

When registering three-dimensional signs, there is a problem since the signs represent the product itself, which further implies that such signs lack distinctiveness, and it is not clear what is protected by this sign. In other words, the question arises: what if protection is provided to a sign that consists in the form of a product that differs in no way, or in a little way, from the usual form used for similar products? In these cases, the procedure for granting the registration of a sign to an entity, which is not entitled to it, would be given the right to monopolize the use of a more favourable market position. In practice, this would mean that the subject designated as the right holder may allow or prohibit another from marking the goods with a trademark, placing such marked goods on the market, or using the sign for advertising purposes, 
because he is the holder of a three-dimensional trademark consisting of a classic for a particular type of goods.

Some well-known examples of three-dimensional signs that are registered and enjoy legal protection through trademarks are a bottle of CocaCola, a Lindt \& Sprüngli Golden Rabbit, a jar of Nutella, and a specific square shape of a Ritter Sport chocolate. On the other hand, many well-known companies have been trying to register a three-dimensional sign for some time, but without success, and the best example of that is the Kit Kat chocolate bar.

\section{Conditions for protection of three- dimensional sign by trademark}

For a certain sign to be protected by a trademark, it is necessary that, on the day of filing the application, i.e., on the day of priority of the trademark application, the legally prescribed conditions are met. The fulfilment of the conditions must also exist at the moment of deciding on the trademark. What is necessary to point out is that the person who performs the registration is free to choose the time in which he wants to do it. More precisely, registration can be done both before use and after the use of a certain sign in the trade of goods and services. Accordingly, conditions such as novelty or originality, which we encounter in patent law, are not necessary. The general condition for the protection of a sign by a trademark is its ability to serve to identify goods and services (Marković \& Popović, 2018, p. 154).

According to the legislation of the Republic of Serbia, the signs of which a trademark may consist and the conditions for trademark protection are prescribed in Article 4 of the Law on Trademarks (2020). It is provided that a trademark may protect a sign which may consist of any characters, in particular words, including personal names, or of drawings, letters, numbers, colours, three-dimensional shapes, shapes of goods or their packaging, combinations of these signs or sounds, under the condition that:

1) that it is suitable for distinguishing in trade of goods or services of one natural or legal person from goods or services of another natural or legal person and

2) that it can be presented in the Register of Trademarks in a way that enables the competent authorities and the public to clearly and precisely determine the subject of protection.

This provision of our legislation is fully in line with EU Directive 2015/16, whose Article 3, paragraph 2 contains an almost identical wording: 
it must be a sign that can be being represented on the register in a manner that enables the competent authorities to determine the clear and precise subject matter of the protection afforded to its proprietor. However, Article 15 of TRIPS still states that, for the registration of a sign and its protection by trademark, there must be two conditions: distinctiveness and a visual display (graphic representation), which is the reason why we analyse these conditions in this paper as well.

\subsection{The distinctiveness of the sign}

The meaning of the word distinctiveness can be expressed only through synonyms such as isolation, uniqueness, difference, separateness. As Ćemalović (2019) explains, the basic function of a sign is to serve to distinguish (differentiate) goods or services from other similar goods or services offered on the market. This function of the sign has an economic nature. It enables undertakings to present their goods or services to consumers or other customers by clearly indicating the source of the goods or services in a way that is recognizable to the extent that the consumer or other customer can, without confusion, easily and confidently choose a product from a specific manufacturer. Therefore, a trademark must meet the condition that an individual can perceive it sensually, i.e., that during the sensory perception of the sign, associations are created about the properties of certain goods (Marković, 2014, p. 186).

That is why there is a ban on the protection of signs that we call generic signs. These are signs that indicate a certain type of goods in their entirety. According to Markovic (2014), we can conclude that, if the registration of such signs were approved, it would mean that any form of communication about the type of product automatically creates the impression that there is only one manufacturer of that product on the market. The overall result is reflected in an inefficient market. Therefore, signs such as "water" for water would be unacceptable.

It should be emphasized, however, that the degree of distinctiveness of the sign is a psychological category, i.e., it is impossible to exclude the subjective experience of the brand from the consumer's perspective. The perception of each individual individually depends on his overall abilities, and above all memory, power of observation, and the like (Marković, 2014, p. 197).

When it comes to three-dimensional signs, there are no precise criteria that could be useful in determining the fulfilment of the conditions of distinctiveness. Such criteria are not defined in European Union law, although, in the field of intellectual property, it is harmonized by accepting the rules of 
the Paris Convention and the Madrid Agreement, but also by adopting EU directives (Timothy, 2000, p. 324). Therefore, it is only possible through the analysis of relevant case law to answer the questions which criteria is used in the assessment of whether in a particular case the condition of distinctiveness is met in order to provide protection to the three-dimensional sign.

Numerous cases show that it is insisted that the form for which protection is sought must be recognizable and not functional (Mwirigi \& Krishnan, 2019, p. 921). One such example is the Bongrain case (Bongrain vs Trademark Request) from $2004^{1}$ in which the applicant for registration in the United Kingdom in 2004 tried to protect a three-dimensional sign consisting of a flower shape. It was interesting that he had the idea to produce French cheese in the shape of a three-dimensional six-pointed flower. Protection was required regardless of the colour of the cheese, the wrapper, or the label that would be placed over the product. In this case, based on the court decision of the Court of Appeals, which followed after Bongrain asked for judicial protection after the refusal of registration, general conclusions were reached regarding the ability of the three-dimensional sign to be registered. Namely, the court decision determined that the shape of the goods may be the subject of a trademark, that it is not a sign that cannot represent a trademark, and that it is necessary to investigate the distinctive character of such a sign on the day of filing the application. The investigation on the distinctive character of a sign aims to determine whether the mentioned sign has a recognizable character or that character is only an embodiment of the nature of the goods. The Court then finds that the distinctiveness of a sign must be assessed according to the association it may evoke in the consumer. In this regard, the legal standard of the average consumer is used, under which the court considers the consumer who is well informed, reasonably informed, and considerate. The prevailing view, at the time, was that, although one such sign could acquire a sufficient level of recognition, the average consumer did not have the habit of associating the origin of goods with the shape or packaging of a product. Therefore, the court concludes that only a sign that deviates greatly from the norms or customs can perform its function of referring to the origin of the product, and thus the application for registration in the case of Bongrain was rejected. The reason for the rejection of the request was the absence of a distinctive element of the sign, although Simon Malynicz claimed on behalf of the Applicant that the average consumer, if he saw such a cheese, would certainly be able, based on

${ }_{1}^{1}$ EWCA Civ 1690, (2004) Available at: https://www.bailii.org/ew/cases/EWCA/Civ/2004/1690. html, Accessed 07.03.2021. 
a "stunningly unusual shape", to easily recognize it in the store and distinguish it from other products of the same type, in that sense, the product has a recognizable character according to the article 3 (1) (b) Directive EU 89/104, which also corresponds to the section 3 (1) (b) of 1994 United Kingdom Trademark Act. Therefore, the Court of Appeals confirmed by this decision that the unusual shape of the product is not a sufficient criterion for the essential recognizability of the product that would ensure the registration of the trademark, in the absence of evidence of distinction acquired through the use of the product.

Another example concerns the judgment of the Court of Justice of the European Union in the case Voss of Norway ASA v. Office for Harmonisation in the Internal Market (Trade Marks and Designs) from 2015. ${ }^{2}$ The mentioned decision of the Court of Justice in the appellate procedure contains parts of the reasoning in which it is precisely explained how the condition of distinctiveness is assessed. Norwegian company Voss requested the protection of a three-dimensional sign consisting of a cylindrical bottle with a cap of another color. The Court's finding was that the three-dimensional sign consisted of components commonly used for the packaging of goods in Classes 32 and 33 of the Nice Agreement Concerning the International Classification of Goods under protection (i.e. classes comprising soft drinks, beer and water, and alcoholic beverages other than beer). The cylindrical shape of the bottle is a typical choice of most manufacturers of similar goods, and therefore it can be concluded that perfect cylindricality, although it has some specifics in this case, does not meet the condition of distinctiveness and that such a shape does not deviate from the customs and norms of the sector.

It was pointed out that the variant of the usual form for a specific type of product is not sufficient for such a sign to be protected by a trademark, and the request of the Norwegian company was rejected.

When we talk about three-dimensional signs we must not omit the case T-677/18 (Galletas Gullón v EUIPO - Incontinental Great Brands) dating 2018 which got its epilogue last year with the judgment of the Court of Justice of the European Union. ${ }^{3}$ In 2015, Galletas Gullón (S. A) applied for registration of the sign and obtaining the EU Community trademark. The request was sent to the European Union Intellectual Property Office (EUIPO). The applicant's request concerned a biscuit-shaped sign. The biscuit consists of

\footnotetext{
${ }^{2}$ C-445-13 Voss of Norway v OHIM, Available at: http://curia.europa.eu/juris/liste.jsf?language= en\&jur=C,T,F\&num $=\mathrm{C}-445 / 13 \% 20 \mathrm{P} \& \mathrm{td}=\mathrm{ALL}$, Accessed 08.03.2021.

${ }_{3}$ Galletas Gullón v EUIPO - Incontinental Great Brands, Available at: http://curia.europa.eu/ juris/document/document.jsf?text $=\&$ docid $=226885 \&$ pageIndex $=0 \&$ doclang $=E S \&$ mode $=1$ st $\&$ dir $=$ \&occ $=$ first\&part $=1 \&$ cid=9042769, Accessed 08.03.2021.
} 
two tiles connected by white cream. Trademark protection was requested for class 30. The application for this trademark was published in the Bulletin of Community Trademarks under the code 2015/86. Intercontinental Great Brands LLC reacted to this application and opposed the mentioned trademark, because, in the same class, cakes, cookies, and crackers, there is already the same sign, the well-known Oreo brand. The decision from 2018 states that the registered trademark has unfairly gained a reputation, using the reputation of the previously protected mark in the sense of Article 8 of Regulation EU 2017/1001. The mentioned article refers to the possibility of opposing the owner of an earlier trademark to the registration of another, someone else's sign that is identical or similar to his sign, regardless of whether the trademark is sought for the same class of products, provided that the previously protected sign is known in the EU, or the territory of a Member State.

Another interesting case in which the question of interpretation of the conditions of distinctiveness was raised was resolved in the case law of the Commercial Court in Barcelona (Judgment No. 123/2019). ${ }^{4}$ It was about a problematic sign of a cookie in the shape of a dinosaur, and the question was asked - is it possible, by giving trademark protection to such a sign, to monopolize the representation of dinosaurs, or should it remain in the public domain? Well-known cake company GALLETAS ARTIACH S.A.U. sued company LA FLOR BURGALESA S.L. "FLORBU" for trademark infringement and non-compliance with unfair competition rules for selling dinosaurshaped cakes. The lawsuit was accompanied by protected signs in Spain (No. 2790850, No. 1582344, and No. 3565114). Galletas Artiach did not refer to a three-dimensional trademark, but the usual representation of dinosaurs. In deciding, the Commercial Court took into account the characteristics of the packaging. Galletas Artiach cookies are sold in individual packaging, while La Flor Burgalesa cookies are sold in family packaging, intended for consumption, as cereals, at home. The plaintiff also submitted market research, which, according to the court, was inappropriate because it included only expensive biscuits on the market, and the respondents were minors. It was emphasized in the procedure that minors (in this case) cannot be presented as average consumers, but should be their parents, i.e. guardians who buy such products. The fact is that, even if the plaintiff referred to a three-dimensional trademark, it would be concluded that such a sign lacks distinctiveness and that the representation of a dinosaur cannot be monopolized in this way. However, in

\footnotetext{
${ }^{4}$ Judgment of Commercial Court in Barcelona 123/2019, Available at: http://trademarkblog. kluweriplaw.com/2019/04/23/jurassic-battle-in-spanish-courts/, Accessed 08.03.2021.
} 
2020 there was a turnaround. Namely, the Court of Appeals, by its decision $629 / 2020^{5}$, changes the decision of the first instance court by confirming the violation of the Dinosaurs trademark (DINOSAURUS) by the company La Flor Burgalesa with its product marked as GALLE SAUROS. However, the existence of the violation was confirmed concerning the Dinosaur sign, which consists of the word, therefore, the verbal sign. No injury would exist in the case of a three-dimensional dinosaur shape.

A rare positive case law case relates to a case marked C-783/18 P between an EU Intellectual Property Office (EUIPO) and a company Wajos GmbH. ${ }^{6}$ In this case, the European Union Intellectual Property Office decided to request the annulment of the judgment of the Court of Justice of the European Union from October 3, 2018, in connection with the application for registration of a three-dimensional trademark of a German company Wajos GmbH. The annulment of the judgment was requested based on Regulation 207/2009 of 26 February 2009 on the Community trademark, which is no longer in force. According to this Regulation, it is not possible to register a trademark if the sign is devoid of any distinctive character.

According to the said Regulation, Wajos GmbH applied for the registration of a three-dimensional sign consisting of a bottle of unusual, cylindrical shape with a lower part wider than the upper (it can be said that the shape for which protection is sought has many physical similarities with ancient amphorae). Under the Nice Agreement of 2001 on the International Classification of Goods, protection is sought for classes 29, 30, 32, and 33 relating to food storage containers, soft drinks, beer, and alcoholic beverages. By a decision from June 2016, EUIPO refused to register such a trademark because the sign did not meet the requirements for protection. The decision is justified by the fact that the sign refers to a product intended for the general public, but the sign consists of a variant of the usual form that other products have. Therefore, the average consumer, with focused or even increased attention, would not be able to distinguish the goods of the applicant from the goods belonging to other economic entities. In 2017, Wajos filed a lawsuit with the European Court of Justice for the annulment of the disputed decision due to the violation of Article 7 of the mentioned Regulation. In this case, the decision was in favour of the producer, and EUIPO was ordered to bear the costs of the dispute. It

\footnotetext{
${ }^{5}$ Judgment of the Court of Appeal in Barcelona No. 629/2020 of March 23, 2020, Available at: https:/www.poderjudicial.es/search/AN/openDocument/20776a3a4dc208d5/20200803, Accessed 08.03.2021.

${ }^{6}$ C-783/18 P - European Union Intellectual Property Office v Wajos GmbH, Available at: http:// curia.europa.eu/juris/liste.jsf?num=C-783/18\&language=EN, Accessed 08.03.2021.
} 
was estimated that the three-dimensional shape is still specific to other products in the industry and that the average consumer can clearly distinguish it from other similar products based on a medium or high level of attention.

From the examples presented, it can be concluded that it is very difficult to determine whether the condition of distinctiveness is fulfilled when it comes to three-dimensional signs. The basic problem lies in the fact that the three-dimensional sign consists of the very shape of the goods that will then be found in circulation. From these examples, we can see that there is a tendency to refuse to provide protection through trademarks to such signs, due to justified fears that this would endanger public order and thus provide a monopoly position to economic entities that do not deserve it. However, the rare examples in which the protection of the three-dimensional sign has taken place, prove that the needs of the market are changing and that it is necessary that the law, in an adequate way, follows the changes.

\subsection{Possibility of graphic representation of the sign}

The possibility of graphical representation of a sign is a condition that implies that the sign can be protected only if it is expressed visually by writing, painting, or graphics (for mathematical and chemical formulas) (Karki, 2005 , p. 500). However, it must be said that this condition, nowadays, is almost surpassed, although it also applies to three-dimensional signs. We can talk about the graphic representation of a sign when we have in mind the sign consisting of drawings, letters, numbers, etc., but in the future, there could be problems if an economic entity wants to protect the sign consisting of smell or touch, or hum that cannot be musically expressed. Great difficulties are caused by olfactory signs - signs that consist of a smell, although back in 1999 the EU Intellectual Property Office (EUIPO) approved the registration of such a sign which was verbally expressed and defined as "the smell of cut grass" (Ćemalović, 2021, p. 136). The problem arose a few years later when a certain Ralph Sieckmann appeared before the Federal Patent and Trademark Court of Germany with a request to register the olfactory sign, and in the application, he even stated the chemical formula of the mark he wanted to protect. In the case of Sieckmann v. German Patent and Trade Mark Office (Sieckmann v Deutsches Patent und Markenamt), ${ }^{7}$ The Federal Court

\footnotetext{
${ }^{7}$ C-273/00 Sieckmann, ECLI:EU:C:2002:748, Available at: http://curia.europa.eu/juris/showPdf. jsf?text $=\&$ docid $=47585 \&$ pageIndex $=0 \&$ doclang $=E N \&$ mode $=1$ st $\&$ dir $=\&$ occ $=$ first $\&$ part $=1 \& \mathrm{c}$ $\mathrm{id}=9617$, Accessed 08.03.2021.
} 
of Patents and Trademarks of Germany first ruled that such a sign lacks the condition of graphic representation, as well as that the sign consisting of a fragrance is not clear, precise, and objective enough, and that it does not perform its function in trade. The Federal Patent and Trademark Court has sought help from the EU Court of Justice. The judgment of the Court of Justice of the European Union determined that scents cannot be represented graphically, because verbal expressions are excessively subjective and vague, and if the scent was presented by a chemical formula, it would be clear only to a very small number of individuals of which smell is about, i.e., many would in formulas simply see the compound expressed in letters and numbers, not the smell (Ćemalović, 2019, p. 137). Unconventional signs are difficult to protect adequately, primarily because there is no uniform practice in their registration, although such signs in trade can clearly distinguish the goods of one manufacturer from the goods of another, with, perhaps even greater success in creating consumer associations about the manufacturer than traditional signs.

Also, with the constant advancement of technology, it should be expected that many types of signs that cannot be represented graphically will emerge, such as holograms or holographic projections, or moving images. Precisely because of that, the condition that the sign can be graphically represented is slowly being abandoned in intellectual property law in Europe, while in the law of the United States this condition was not even set.

\section{Conclusion}

Accelerated technological development, but also globalization, have caused significant changes in the field of intellectual property protection. New expressions of human creativity, which must be ensured legal protection, appear almost every day, which is why it is necessary to adapt intellectual property law to all innovations brought by technological progress, including the desire of manufacturers to use interesting, unconventional signs to make their products recognizable and acquire as wide a circle of consumers as possible. A big problem with the registration of a three-dimensional sign is related to the fact that this sign represents the shape of the product itself or its packaging. Both of the mentioned elements of the three-dimensional sign are elements that are typical when we talk about legal protection provided through design. Therefore, there must be a strict criterion according to which it will be possible to register three-dimensional signs and be protected by a trademark, which will enable their holder to constantly take advantage of the monopoly position. 
The analysis of the mentioned case law of both national courts and the Court of Justice of the European Union shows that a clear position is not taken on the issue of criteria for assessing whether the condition of distinctiveness is met in a particular case or not. The main reason for the lack of reliable criteria is the hasty regulation of unconventional signs before the theory has built certain attitudes so that in the current situation the doctrine does not offer the answers that practice requires when deciding in specific cases. With the help and guidelines of the World Trade Organization and the World Intellectual Property Organization, an adequate solution should be found in defining the conditions for the protection of unconventional signs, and thus three-dimensional signs.

\section{Petrović Z. Milica}

Master pravnik, doktorand na Pravnom fakultetu Univerziteta u Kragujevcu, asistent na Pravnom fakultetu za privredu i pravosuđe u Novom Sadu, Univerzitet Privredna akademija u Novom Sadu, Srbija

\section{USLOVI ZA PRUŽANJE PRAVNE ZAŠTITE TRODIMENZIONALNIM OZNAKAMA U PRAVU ŽIGA}

REZIME: Potreba za definisanjem trodimenzionalnih žigova i utvrđivanjem uslova za registraciju nastala je kao posledica sve bržeg tehnološkog razvoja. Promene na tržištu i promene u ponašanju privrednih subjekata rezultiraju upotrebom znakova za obeležavanje robe koji se značajno razlikuju od tradicionalnih žigova. Ono što je problematično jeste činjenica da oznaka, u ovom slučaju, predstavlja sam proizvod, što implicira da takvi znakovi ove vrste nemaju distinktivnost. Analiza pomenutih slučajeva iz prakse, koje je izneo autor, imaju za cilj da pokažu razlike u mišljenjima sudova u pogledu kriterijuma po kojima će se ocenjivati da li je uslov distinktivnosti zadovoljen u konkretnom slučaju ili nije. Glavni razlog nedostatka pouzdanih kriterijuma je ishitreno regulisanje nekonvencionalnih znakova i nedostatak usaglašenih, jasnih pravila kako na nivou Evropske unije, tako i na globalnom nivou. Autor smatra da je neophodno da Svetska trgovinska organizacija ili Svetska organizacija za intelektualnu svojinu 
ponude smernice u okviru kojih će biti obezbeđena odgovarajuća zaštita nekonvencionalnih znakova na nacionalnom nivou kako bi se eliminisalo stanje pravne nesigurnosti koje može nastati prilikom podnošenja zahteva za zaštitu trodimenzionalnih znakova.

Ključne reči: trodimenzionalna oznaka, nekonvencionalna oznaka, pravo žiga, pravo intelektualne svojine.

\section{References}

1. Blakely, T. W. (2000). Beyond the international harmonization of trademark law: The community trade mark as a model of unitary transnational trademark protection. University of Pennsylvania Law Review, 149 (1), pp. 309-354

2. Chu-Hui, L. \& Liang-Hsiu, L. (2017). Retrieval of 3D trademark based on discrete fourier transform. In: Kuinam J. Kim, Nikolai Joukov (eds.), International Conference on Mobile and Wireless Technology, (pp. 620627) Singapore: Springer

3. Ćemalović, U. (2019). Pravo intelektualne svojine i digialna transformacija: neka aktuelna pitanja [Intellectual property law and digital transformation: Some current issues]. Beograd: Institut za evropske studije

4. Karki, M. M. S. (2005). Nontraditional Areas of Intellectual Property Protection: Colour, Sound, Taste, Smell, Shape, Slogan and Trade Dress. Journal of Intellectual Property Rights, 10 (6), pp. 499-506

5. Lukose, L. P. (2015). Non-Traditional Trademarks: A critique. Journal of the Indian Law Institute, 57 (2), pp. 197-215

6. Marković, S. (2014). Pravo intelektualne svojine i informaciono društvo [Intellectual property law and the information society]. Beograd: Službeni glasnik

7. Marković, S. \& Popović, D. (2018). Pravo intelektualne svojine [Intellectual property law]. Beograd: Pravni fakultet Univerziteta $\mathrm{u}$ Beogradu

8. Mwirigi C. K., \& Krishnan, S. (2019). Registrability of non-conventional trademarks: A critical analysis. International Journal of research and analytical reviews, 6 (1), pp. 914-923

9. Setiawan A., Sulistianingsih, D. \& Bhakti Yudistira, I. (2017). NonTraditional Trademarks in Indonesia: Protection under the Laws and Regulations (An Intellectual Property Law). Journal of Indonesian legal studies, 2 (2), pp. 123-130 
10. Regulation (EU) on the European Union trade mark, 2017/1001, OJL 154, 16.6.2017, pp. 1-99, Downloaded 2020, February 25 from https://eurlex.europa.eu/legal-content/EN/TXT/?uri=CELEX\%3A32017R1001.

11. Zakon o žigovima, [Law on Trademarks of the Republic of Serbia]. Službeni glasnik $R S$, no. 6/20 